\title{
The First Structurally Determined Ruthenium Nitrate Complex of Chelating Diphosphine Ligand
}

\author{
Won K. Seok \\ Department of Chemistry, Donggtik Lnwersity, Seoul 100-715, Korea. E-mail: w'onkseokaldongguk edu \\ Received October 28, 2006
}

Key Words : Ru nitrate complex. Chelating dppm ligand. Bi-dentate fashion CAN

Among the reported functionalized complexes. oxo and nitrido nuthenium or osmium complexes containing multidentate nitrogen-based ligands have proven to be especially valuable in mechanistic and oxidative catalytic studies. ${ }^{1}$ During the last decade the chemistry of inorganic and organometallic complexes with phosphine ligands has been well developed to apply them to catalysts. " Therefore it is of interest to combine these two characteristics to prepare oxo complexes surrounded by the phosphine ligands.

A general way to șinthesize Ru-oxo complexes can be started from the related Ru-chloro species wia the corresponding Ru-aquo complexes. Oxidation of the Ru-aquo complexes by a powerful one-electron oxidant like $\left(\mathrm{NH}_{4}\right)_{\text {s- }}$ $\mathrm{Ce}\left(\mathrm{NO}_{3}\right)(\mathrm{CAN})$ can lead to the formation of the final products. 'Accordingly we prepared and characterized ruthenium di-chloro complexes. $\left[\mathrm{Ru}(\mathrm{dppm})_{2} \mathrm{Cl}_{2}\right]$ and $\left[\mathrm{Ru}(\mathrm{dppe})_{2} \mathrm{Cl}_{2}\right]$. by using the reaction of $\left[\mathrm{Ru}_{3}\left(\mathrm{PPh}_{3}\right)_{2} \mathrm{Cl}_{2}\right]$ with the dppm or dppe ligand $\left(\mathrm{PPh}_{3}\right.$ : triphenylphosphine dppm: 1,1-bis(diphenyllphosphino)methane dppe: 1.2-bis(diphenylphosphino)ethane). ${ }^{3}$ A ruthenium di-aquo complex. ¡Ru(dppm)s$\left.\left(\mathrm{H}_{2} \mathrm{O}\right)_{2}\right]\left(\mathrm{PF}_{6}\right)_{2}$. can be obtained by adding $\mathrm{AgClO}_{4}$ to the $\left[\mathrm{Ru}(\mathrm{dppm})_{2} \mathrm{Cl}_{2}\right]$ complex followed by precipitating with saturated $\mathrm{NH}_{4} \mathrm{PF}_{6}$ solution. ${ }^{4} \mathrm{CAN}$ in $\mathrm{HClO}_{4}$ was added into the di-aquo complex and the residue was put into the refrigerator. The crỵstals obtained bỵ diffusion method from acetone/water show the formation of an unexpected complex rather than the desired nuthenium di-oxo species.

ln organic chemistry CAN has been known to catalyze the ring opening reaction of different epoxides through the formation of nitrate compound in aprotic solvent. which is a key intermediate in the stereoselective syntheses and is useful for a variety of oxidative transformations. ${ }^{5}$ The photochemical reaction of CAN with olefins also produced 1.2nitrate adduct via the initial formation of nitrate radical. ${ }^{6}$ It is quite interesting to show that $\mathrm{CAN}$ can be used to prepare the nitrate complexes in coordination chemistry:

Here we found out that the reaction of $\mathrm{CAN}$ in perchloric acid with the di-aquo complex gave the unusual nitrate complex rather than the di-oxo complex. ${ }^{7}$ In the reaction it is presumed that the more labile aquo group in the di-aquo complex can be quickly substituted by the nitrate anion in a bi-dentate fashion. which is more favorable in entropy.

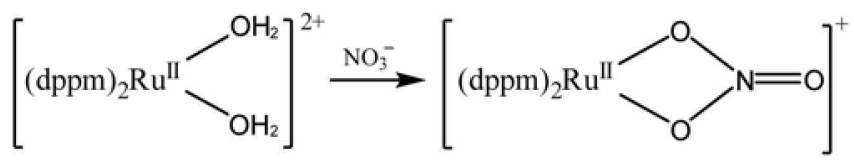

The structure of the nitrate complex. which turned out to be $\left[\mathrm{Ru}^{\square}(\mathrm{dppm})_{2}\left(\mathrm{O}_{2} \mathrm{NO}\right)\right]\left[\mathrm{ClO}_{4}\right]$. has been determined from $\mathrm{X}$-ray diffraction. The perspective view with the numbering scheme of the atoms is shown in Figure 1.

The complex consists of discrete $\left[\mathrm{Ru}^{\mathrm{II}}(\mathrm{dppm})_{2}\left(\mathrm{O}_{2} \mathrm{NO}\right)\right]^{+}$ and $\mathrm{ClO}_{4}^{-}$. which contains a ruthenium atom surrounded by two chelating diphosphine ligands and the nitrate ligand. The presence of the nitrate ligand coordinated to the ruthenium metal was confimed by a singlet resonance at 13.8 $\mathrm{ppm}$ in the ${ }^{14} \mathrm{~N}$ NMR spectrum and that of the percllorate anion by a sharp singlet peak at $1.01 \mathrm{ppm}$ in the ${ }^{35} \mathrm{Cl}$ NMR spectrum. The magnitude of the splitting of peaks at 1435 and $1232 \mathrm{~cm}^{-1}$ observed in the FT IR spectrum re-confimed that the nitrate ligand coordinated to the metal in a bi-dentate way.

The coordination polyhedron around the ruthenium metal is described as a severely distorted octahedron. Selected bond distances and angles listed in Table 1 are comparable with other structurally characterized complexes containing the dppm ligand.

The Ru-P bond distances range from $2.277(1)$ to $2.393(1)$ A. The phosphorous atoms coordinated to ruthenium metal deviate strongly from a square planar arrangement as noted by the P1-Ru-P2 and P3-Ru-P4 bond angles of less than $90^{\circ}$ $\left(70.76(3)^{\circ}\right.$ and $70.35(3)^{\circ}$. respectively) for two phosphorous atoms bonded to the ruthenium metal cis to one another and by the P1-Ru-P4 and P2-Ru-P3 angles of less than $180^{\circ}$ $\left(103.8(1)^{\circ}\right.$ and $102.7(1)^{\circ}$, respectively) for those in the opposite position.

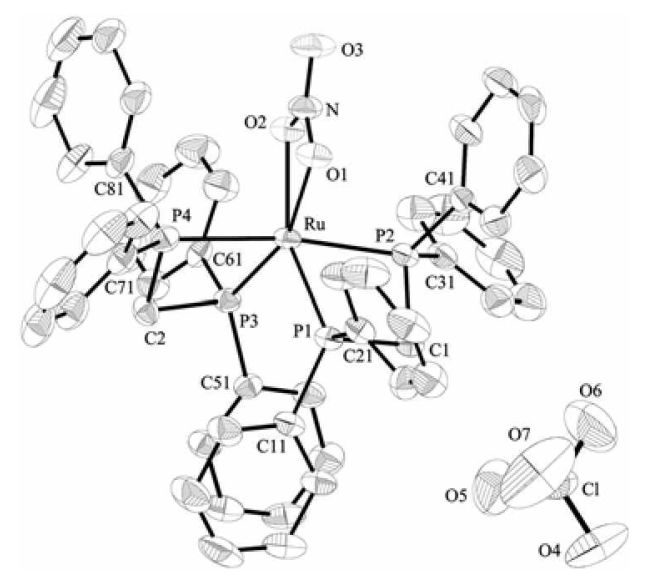

Figure 1. Molecular structure of $\left[\mathrm{Ru}(\mathrm{dppm})_{2}\left(\mathrm{O}_{2} \mathrm{NO}\right)\right]\left[\mathrm{ClO}_{4}\right]$ in the crystal. Displacement ellipsoids are shown at the $50 \%$ probability level. Hydrogen atoms have been omitted for clarity 
Table 1. Selected bond distances and angles

\begin{tabular}{|c|c|c|c|c|}
\hline Ru-Pl & 2.284(1) Rll-P2 & $2.354(1)$ & Rul-P3 & $2.277(1)$ \\
\hline Rul-P4 & 2.393 (1) Rul-Ol & $2.188(2)$ & $\mathrm{Rll}-\mathrm{O} 2$ & $2.184(2)$ \\
\hline PI-CI & $1.837(3) \mathrm{PI}-\mathrm{C} 1 \mathrm{I}$ & $1.807(3)$ & PI-C21 & $1.828(3)$ \\
\hline $\mathrm{P} 2-\mathrm{Cl}$ & $1.815(3) \mathrm{P} 2-\mathrm{C} 31$ & $1.812(3)$ & $\mathrm{P} 2-\mathrm{C} 41$ & $1.815(3)$ \\
\hline $\mathrm{P} 3-\mathrm{C} 2$ & $1.840(3) \mathrm{P} 3-\mathrm{C} 51$ & $1.804(3)$ & $\mathrm{P3}-\mathrm{C} 61$ & $1.823(3)$ \\
\hline $\mathrm{P} 4-\mathrm{C} 2$ & $1.818(4) \mathrm{P} 4-\mathrm{C} 71$ & $1.816(3)$ & $\mathrm{P} 4-\mathrm{C} 81$ & $1.813(4)$ \\
\hline $\mathrm{N}-\mathrm{Ol}$ & $1.272(3) \mathrm{N}-\mathrm{O} 2$ & $1.282(3)$ & $\mathrm{N}-\mathrm{O} 3$ & $1.216(4)$ \\
\hline Pl-Ru-P2 & $70.76(3)$ P3-Ru-P4 & $70.35(3)$ & Pl-Ru-P4 & $103.8(1)$ \\
\hline P2-Ru-P3 & $102.7(1)$ Ol-Ru-O2 & $58.9(1)$ & Ol-Ru-Pl & $1046(1)$ \\
\hline O2-Ru-P3 & $107.2(1)$ O2-Ru-P4 & $94.1(1)$ & $\mathrm{Ru}-\mathrm{P} 4-\mathrm{C} 2$ & $93.2(1)$ \\
\hline Ru-P3-C2 & $96.5(1) \quad \mathrm{Ru}-\mathrm{Pl}-\mathrm{Cl}$ & $96.6(1)$ & Ru-P2-Cl & $94.8(1)$ \\
\hline $\mathrm{Ru}-\mathrm{Ol}-\mathrm{N}$ & $\mathrm{Ru}-\mathrm{O} 2-\mathrm{N}$ & $93.1(2)$ & $\mathrm{P3}-\mathrm{C} 2-\mathrm{P} 4$ & $94.8(2)$ \\
\hline $\mathrm{Pl}-\mathrm{C} 1-\mathrm{P} 2$ & $94.7(2) \quad \mathrm{Ol}-\mathrm{N}-\mathrm{O} 2$ & $114.7(3)$ & $\mathrm{O} 2-\mathrm{N}-\mathrm{O} 3$ & $122.8(3)$ \\
\hline $\mathrm{O} 1-\mathrm{N}-\mathrm{O} 3$ & $122.5(3) \mathrm{C} 71-\mathrm{P} 4-\mathrm{C} 81$ & $105.2(2)$ & $\mathrm{C} 51-\mathrm{P} 3-\mathrm{C} 61$ & $102.4(1)$ \\
\hline C11-PI-C2 & $101.6(1) \mathrm{C} 31-\mathrm{P} 2-\mathrm{C} 41$ & $105.2(2)$ & & \\
\hline
\end{tabular}

The $\mathrm{O}-\mathrm{Ru}-\mathrm{O}$ bite angle of the nitrate ligand containing $\mathrm{N}$ at the apical position is $58.9(1)^{\circ}$ with $\mathrm{Ru}-\mathrm{O}$ distances of 2.188(2) and 2.184(2) A. The N-O3 distance to the uncoordinated oxygen atom in the nitrate ligand is $1.216(4) \AA$. The bonding parameters in the $\left[\mathrm{Ru}^{\mathrm{II}}(\mathrm{dppm})_{2}\left(\mathrm{O}_{2} \mathrm{NO}\right)\right]\left[\mathrm{ClO}_{4}\right]$ complex are comparable with those of other mono-nitrate complexes. which show Ru-O distances in the range of 2.151-2.391 $\AA$ and $\mathrm{O}-\mathrm{Ru}-\mathrm{O}$ angles in the range of 50.3$59.9^{\circ}{ }^{11}$ However the averaged M-O distances for oxygen atoms of the nitrate ligand attached to the Group III metals fall in a range of 2.255-2.646 $\mathrm{A}$ for bis-nitrate complexes. ${ }^{11}$ For lanthanide tris-nitrate complexes, the averaged distance reveals 2.151-2.391 $A$ and the averaged O-M-O (M = Eu or Cd) bond angles of $48.5-56.5^{\circ} .^{12}$

Generally the O-M-O bond angles decrease as the number of the nitrate ligands increase. The averaged bond distance of two oxygen atoms of the coordinated nitrate group in the complex is comparatively short. The nitrate anion can also act as a uni-dentate coordinating ligand with only one of two oxygen atoms to the metal: in this case. however the distance is getting longer. ${ }^{13}$ Even if reports on the preparation of mono-nitrate complexes are not unconmonon. nevertheless most of them are related to uni-dentative nitrate complexes. ${ }^{16.14}$ Although products of $\left[\mathrm{Ru}^{\mathrm{II}}(\mathrm{dppe})_{2}\left(\mathrm{NO}_{3}\right)\right]\left[\mathrm{ClO}_{4}\right]$ were obtainable. we have been unable to characterize and grow cry stals suitable for $\mathrm{X}$-ray analysis.

\section{$\mathrm{X}$-ray Crystallography}

Cnstal data. $\mathrm{C}_{5 i 1} \mathrm{H}_{44} \mathrm{ClNO}_{7} \mathrm{P}_{4} \mathrm{Ru}$. monoclinic. space group $P 21_{1} / c$ (No. 14), $a=11.048(2) . b=24.527(5) . c=17.569(4)$ A. $\beta=100.08(3)^{\circ}, V=4687.1(16) \AA^{3} . R_{\text {int }}=0.0905, Z=4, T$ $=200 \mathrm{~K}, d_{c u l}=1.462 \mathrm{~g} / \mathrm{cm}^{3}$. A STOE IPDS instrument equipped with an image plate area detector and employing graphite monochromated MoKa radiation $(\lambda=0.71073 \AA)$ was used for data collection. A total of 40457 (11043 independent) reflections were collected. which yielded 5969 reflections observed for $[I>2 \sigma(I)]$. The structure was solved by direct methods and subjected to a full-matrix leastsquares refinement procedure for all non-hydrogen atoms. The final agreement factors were $R_{1}=0.0975$ (all data). $R_{1}=$ 0.0403 for $[I>2 \sigma(I)], \mathrm{w} R_{2}=0.0696$ and $\mathrm{w} R_{2}=0.0607$ for $[I$ $>2 \sigma(l)]$ (753 parameters. 0 restraints). Crystallographic data in CIF format have been deposited at the Cambridge Crystallographic Data Centre. CCDC No. 299067.

Acknowledgement. This work was supported by Dongguk University: The author is greatly indebted to professors Konstantin Karaghiosoff. Thomas M. Klapötke. Peter Klüfers and Dr. Peter Mayer of Ludwig Maximilians University of Munich.

Supplementary Information Available: Experimental procedures for the complexes in references 3.4 and 7 studied here are available via the internet at http://www.kcsnet.or.kr/blics.

\section{References}

1. (a) Huynth. M. H. V.: Meyer. T. T.: Jameson. D. L. Horg. Chen 2005. Ht, 3657. (b) Seok, W. K. Meyer, T. J. Inorg. Chem 2005. 44. 3931 and references therein. (c) Zhang. J.; Liang, J.-L.: Sun. X.-R.: Zhou. H.-B.; Zhu, N.-Y.: Chan. P. W. H.: Che. C.-M. Inorg. Chem. 2005, H. 3942. (d) Wu, A.; Dehestani, A.: Saganic, E.: Crevier. I. I.: Kaminshy. W. Cohen. D. E.: Mayer. J. M. Inorg. Chim . Acta 2006. 359.2842 .

2. (a) Espinet. P.: Soulantica. K. Coond Chem. Rev 1999. 193.499. (b) Menges, F.: Neuburger, M.; Ptaltz, A. Org. Lett. 2002. f, 4713. (c) Pickett, T. E.; Roca, F. X.: Richards. C. J. J. Ong Chem 2003, 68 , 2592.

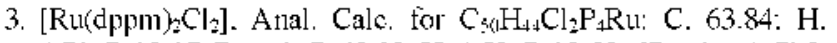
4.71: P. 13.17. Found: C. 63.02: H. 4.52: P. 12.58. [Ru(dppe) $)_{2} \mathrm{Cl}_{2}$ ]. Anal. Calc. for $\mathrm{C}_{52} \mathrm{H}_{48} \mathrm{Cl}_{2} \mathrm{P}_{4} \mathrm{Ru}: \mathrm{C}, 64.47: \mathrm{H}$. 4.99; $\mathrm{P}, 12.79$. Found: $\mathrm{C}, 65.21 ; \mathrm{H}, 4.78:$ P. 12.16 .

4. [Ru(dppm)s $\left.\left(\mathrm{H}_{3} \mathrm{O}\right)_{2}\right]\left(\mathrm{PF}_{4}\right)_{2}$, Anal. Calc. for $\mathrm{C}_{3}\left(\mathrm{H}_{4} \mathrm{~F}_{12} \mathrm{O}_{2} \mathrm{P}_{4} \mathrm{Ru}: \mathrm{C}\right.$. 50.22: H. 4.05: P. 15.54. Found: C. 50.89: H. 4.18: P. 14.92. [Ru(dppe $)_{2}\left(\mathrm{H}_{2} \mathrm{O}_{2}\right]\left(\mathrm{PF}_{6}\right)_{2}$. Antal. Calce for $\mathrm{C}_{4_{2}} \mathrm{H}_{42} \mathrm{~F}_{12} \mathrm{O}_{2} \mathrm{P}_{6} \mathrm{Rul}$ : C. 51.03: H. 4.28: P. 15.18. Found: C. 52.02: H. 4.43: P. 44.76.

5. (a) di Fabio, R; Rossi, T; Thomas. R. J. Tetrahedron Lett. 1997. 38. 3587. (b) Nair. V.: Panicker. S. B.: Nair. L. G.: George. T. G.: Augustine, A. Symlett. 2003, 2, 156

6. Baciocchi, E; Giacco. T. D.: Murgia, S. M:; Sebastiani. G. V. Tetrahedron 1988, 44,6651 .

7. $\left[\mathrm{Ru}(\mathrm{dppm})_{2}\left(\mathrm{NO}_{3}\right)\right]\left(\mathrm{ClO}_{4}\right)$. Anal. Calc. for $\mathrm{C}_{50} \mathrm{H}_{44} \mathrm{ClNO}-\mathrm{P}+\mathrm{Ru}: \mathrm{C}$. 58.23: $\mathrm{H}, 4.30$ : P. 12.01. Found: C. $57.31 ; \mathrm{H}, 4.41 ;$ P. 11.57 .

8. (a) Karayannis. N. M.: Sonsino. S. D; Mikulski, C. M: Strocko. M. J.: Pytlewski. L. L: Labes. M. M. Inorg. Chim Acta 1970, 4. 141. (b) Briggs. E. M.: Hill. A. E. J. Chem. Soc. \& 1970, 2008.

9. (a) de Priest, J.: Zheng, G. Y.: Woods. C: Rillema. D. P: Mikirova. N. A.: Zandler. M. E. Inorg. Chim Acta 1997. 264.287. (b) Gimeno. T.: Lastra. E.: Madrigal. C.: Graiff. C.: Tiripicchic. A. J. Organonet Chem. 2001.637 .463$.

10. (a) Lasker, I. R.: Das, D.: Chaudhuri. N. R.; Mostafa. G.: Welch. A. J. Polvhedron 1998. 17, 1363. (b) Reger. D. L:; Wright, T. D: Smith. M. D. Inorg. Chim Acta 2002. 33 t, 1 . (c) de Almeida. K C. S.: Martins. T. S.: Isolani. P. C.: Vicentini. G. ZukermanSchpector. T. J. Solid State Chem. 2003. 171.230.

11. (a) Levason. W: Patel. B.: Porham. M. C.: Reid. G.: Webster. M. Polvhedron 2001, 20,2711. (b) Fukuda, Y; Nakao, A.: Hayashi. K. J. Chem. Soc. Dalton Trans. 2002. 527.

12. (a) Gradeff. P. S:; Yunlu. K.; Deming, T. J: Olofson. J. M:; Ziller. J. W. Evans. W. T. Inorg Chem 1989. 28. 2600 , (b) Cotton. S. A.: Noy. O. E.: Liesener. F.: Raithby. P. R. horg. Chin. Acta 2003. $3+4.37$ and references therein. (c) de Souza. H. K. S.: Garrido Pedrosa, A. M.: Marinho. E. P.: Batista, M. K. S.; Araujo Melo, D. M.; Zinner. K.; Zinner. L. B.: Zukerman-Schpector. J:- Vicentini. G. J. Solid State Chem 2003, 171, 242.

13. (a) Anderson. R. T.: Hagback. P. H.: Steel. P. T. horg. Chim. Acta 1999. 28+. 273. (b) Gramlich. V: Lubal. P.: Musso. S.: Anderegg. G. Heh: Chim. Acta 2001. 84.623.

14. Mueting. A. M.: Alexander, B. D.: Boyle, P. D.; Casalnuovo, A. L.: Ito. N.: Tohnson. B.: Pignolet. L. H. horg Symeses 1992. 29. 279. 